University of Rhode Island

DigitalCommons@URI

The Rhode Island Current Conditions Index

Economics

$11-2003$

\title{
Rhode Island Current Conditions Index - November 2003
}

Leonard Lardaro

University of Rhode Island, lardaro@uri.edu

Follow this and additional works at: https://digitalcommons.uri.edu/ricci

Part of the Econometrics Commons

Terms of Use

All rights reserved under copyright.

\section{Recommended Citation}

Lardaro, Leonard, "Rhode Island Current Conditions Index -- November 2003" (2003). The Rhode Island Current Conditions Index. Paper 130.

https://digitalcommons.uri.edu/ricci/130

This Article is brought to you for free and open access by the Economics at DigitalCommons@URI. It has been accepted for inclusion in The Rhode Island Current Conditions Index by an authorized administrator of DigitalCommons@URI.For more information, please contact digitalcommons-group@uri.edu. 


\section{Current Conditions Index \\ LEONARD LARDARO URI \\ Also available online: http://members.cox.net/lardaro/}

Volume $X$, Number 1

November 2003

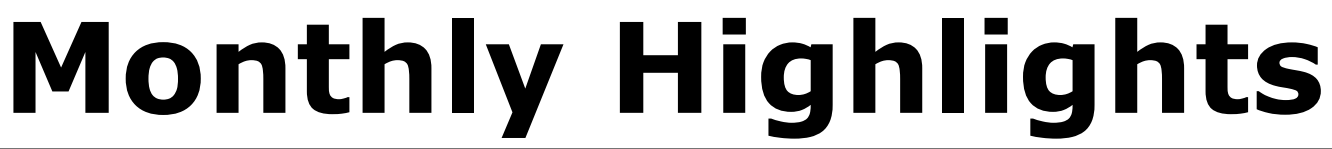

Rhode Island's fourth quarter performance remained strong, as the November Current Conditions Index rose to 83, its highest level since March of 2000. In November, ten of the twelve CCI indicators showed improvement overall, several displaying sharp improvement. The CCI has now exceeded its year-earlier value for every month since May of this year. The key trends in Rhode Island's economy continue to be retail strength assisted by improving US consumer sentiment, declining layoffs, rising new home construction, and lower unemployment.

Retail Sales, which has been a stellar performer throughout this recovery, grew at a 7.1 percent rate in November (although there are some measurement problems at present with this statistic). US Consumer Sentiment once again rose at a double-digit rate compared to last year (+11.4\%), sustaining its recent trend of values above 90 . Clearly, the improving stock market and less bleak job prospects have finally allowed this indicator to move from its earlier doldrums. Volatility in new home construction continued in November, as Single-Unit Permits rose by 14.1 percent compared to last November. This indicator has now risen at double-digit rates for four of the last five months.

\begin{tabular}{lr}
\multicolumn{2}{c}{ CCI Indicators - \% Change } \\
Government Employment & -0.5 \\
US Consumer Sentiment & $11.4 \mathbf{~ Y}$ \\
Single-Unit Permits & $14.1 \mathbf{Y}$ \\
Retail Sales & $7.1 \mathrm{Y}$ \\
Help Wanted Advertising & -6.5 \\
Priv. Serv-Prod Employment & $0.7 \mathbf{~ Y}$ \\
Man-Hours Manufacturing* & $0.7 \mathbf{Y}$ \\
Manufacturing Wage* & $1.4 \mathbf{Y}$ \\
Labor Force & $0.4 \mathbf{Y}$ \\
Benefit Exhaustions & $-1.4 \mathbf{Y}$ \\
New Claims & $-3.6 \mathbf{Y}$ \\
Unemployment Rate & $-9.3 \mathbf{Y}$ \\
\multicolumn{2}{c}{ Y = Improved Value } \\
$\quad$
\end{tabular}

Labor demand overall continues to strengthen, although Help Wanted Advertising fell again, but at its lowest rate in the last year $(-6.5 \%)$. Long-term unemployment, as measured by Benefit Exhaustions, fell by 1.4 percent, remaining below a 20,000 annual rate. New Claims for Unemployment Insurance, the most timely measure of layoffs, fell by 3.6 percent in November, which follows a double-digit decline in October, the continuation of an improving trend that began in March. Rhode Island's Unemployment Rate, 4.9 percent, remained well below its value last November (of $5.4 \%$ ) but was half a percentage point higher than its level in October. The good news is that this rate remains well below the national rate and has stayed below 5 percent for three months. The "bad" news is that the recent low value of 4.5 percent (September) will soon be revised upward when new data are released in February.

Rhode Island's manufacturing labor market actually improved in November as Manufacturing Man-hours rose (believe it or not!) by $0.7 \%$ while the Manufacturing Wage increased at an above one-percent rate for only its third time in the last six months. Private Service-Producing Employment grew more slowly in November (+0.7), continuing a weak stretch that began in April (although this too might be revised away). Finally, ongoing budget difficulties resulted in another fall in Government Employment $(-0.5 \%)$, a continuation of the downside of efforts taken to balance state and local budgets.

Rhode Island's performance in the fourth quarter continues to be very encouraging. Keep in mind, however, that this is an uneven recovery, so it is quite possible that December's CCI will not indicate as much economic momentum as we have seen for both October and November. Clearly, though, Rhode Island's economy has gained momentum since its earlier flirtation with a double-dip recession at the beginning of 2003.

\section{Current Conditions Index}

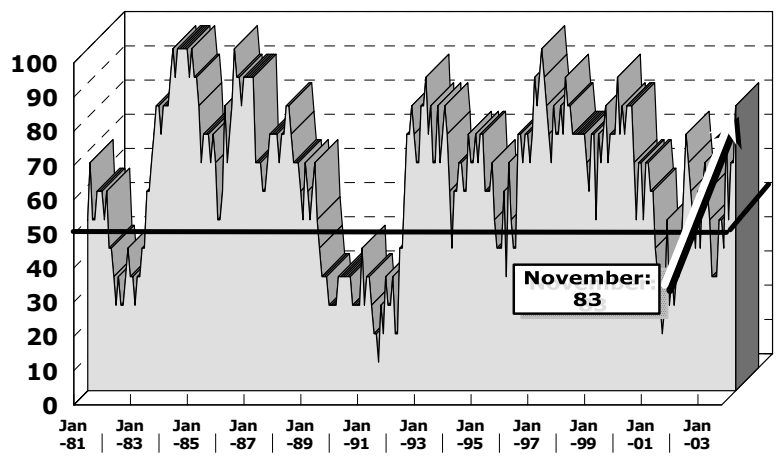

\begin{tabular}{|c|c|c|c|c|c|c|c|c|c|c|c|c|}
\hline & Jan & Feb & Mar & Apr & May & Jun & Jul & Aug & Sep & Oct & Nov & Dec \\
\hline 2002 & 58 & 75 & 67 & 58 & 42 & 33 & 50 & 42 & 50 & 58 & 50 & 50 \\
\hline 2003 & 33 & 33 & 33 & 50 & 50 & 42 & 67 & 50 & 67 & 67 & 83 & \\
\hline
\end{tabular}

